\title{
先秦漢語に打ける “其” の機能について
}

\author{
山 崎 直 樹 \\ (早稲田大学大学院)
}

This paper argues that "qi (其)" of Archaic Chinese in this sentence “王室其有間王位” is originally a anaphoric pronoun and has the two functions simultaneously, as follows:

1. "qi" focuses its preceding noun phrase.

2. "qi" changes its following predicate phrase into a nominal expression with subjunctive mood.

This paper also proposes the hypothesis which explanes how "qi" has obtained these functions, and intends to synthesize the various functions of the pronoun "qi", which have been explaned respectively by many Chinese linguists.

1. 序

2. 先行諸説の検討

\section{1. 主語との関係}

2.1.1. 藤堂1953説

2.1.2. Dobson 1962 説

2.1.3. まとめ

2.1.4. 主語の焦点化

2.2. 代名詞以外のものととらえる説 2.2.1. 品詞とその意味

\section{1. 序}

本稿》では, 先秦漢語の “王室其有間王 位.”（王室には王位をねらら者が出るである う。)2)のよな文の主語と述語の間に現れる “其”を，三人称代名詞に由来し，次の二つ の機能を同時にもつものととらえる。

甲. 主語の焦点化。

乙. 述語句を名詞的表現に転換することによ り仮定法的ムードをすつ句にする。

そして，上記ふたつの機能をるつに至った 過程を設定する仮説を提出し, 従来, 個別に

\subsection{2. “其” の位置}

\section{3. あるべき方向}

3. “其” の用法

3.1. 属格

3.2. 主語・目的語になる節

3.3. 従属節

3.3.1. 前提節

3.3.2. 㷌結節

4. 結

説明されてきた “其”のいくつかの機能を統 合することを目指す。

資料は主に『春秋左氏伝』を用いる。それ は，本稿で扱う形式が生産的であるテクスト は, 他に『書経』『詩経』『論語』『礼記・檀 弓篇』『国語』があるが，用例の絶対量とい う点では,『左伝』に勝るものはないからで ある。以下の用例で，（哀 1），（昭26）のよ らに記してあるものは，それぞれ『左伝』の 「哀公元年」「昭公26年」を指す。 


\section{2. 先行諸説の検討}

2.1. 主語との関係

この “其”を主語との関係で論じたものに, 藤堂1953と, Dobson 1962 がある。

\subsection{1. 藤堂1953説}

藤堂1953は，イェスペルセンの用語を借り て,この “其”を「想起詞 reminder」とと らえている。「想起詞」とは，「主題となる語 をたえず反復して，その主題について述へてて いることを相手に想起させ, 語脈を一貫する」 ものである。そして次のように述べる；「上 古漢語もまた主題詞を反復するのではないが， 指示詞を想起詞的に用いて相手の注意を喚起 しつつ，語脈をつなぐ…...」(195)。

\subsubsection{Dobson 1962 説}

Dobson 1962 は, 先に挙げた例のような文に 対して, 主語が強調のため外固され, 主語の 人称にかかわりなく，三人称の承前代名詞 “其”が，主語のあった位置を埋めている， ととらえている (89-91)。

この, Dobson 1962 のいうところは, 次の ように解釈できる。日本語の例でいえば，主 語が外直されていない形式が，(1)a の文とす れば，外置されたのは，(1)bの文である。

(1) a [南極は氷の世界である]

b [南極 $\mathrm{i}$ [それ i は氷の世界である] ( $i=$ 同一指示)

Dobson 1962 は, (1) a bに挙げた現象と類 似のものととらえているのであろら。しかし この場合, “其”をあくまで代名詞として使 っていることにすると, 次の,

(2) a 吾其奔也。(僖23)「わたしは逃げよう。」

b 女其行乎。(僖24）「扰ま克は行け。」 のように, 主語が明らかに一・二人称の代名 詞である場合が問題になる。Dobson 1962 は これについて，特に説明をしていないが，[代 名詞 $] \rightarrow$ [主語外置の標識 $]$ とい変化の過 程で，人称の一致の機能を失ったとする説明 をすることは可能である。本稿の問題と直接 に関連はしないが，三人称代名詞がコピュラ
に変化していく過程で, 人称の一致を喪失し， 主語が一・二人称でもその三人称代名詞由来 のコピュラを用いる言語があることが, Benveniste 1966 に述べられている（邦訳177）。 上の解釈も不自然なものではあるまい。

\subsection{3. まとめ}

上述の二説は，次のよらな意義をもってい る。つまり，一般に “其”という表記をむつ 形態素は三人称代名詞とされているが，先の 例の文中の “其” もやはり，(1)品詞としては 三人称代名詞で，機能的には主語とかかわり をもち (藤堂)，(2)その機能とは，主語を強 調のため外置したといら標識である(Dobson 1962)。

\subsection{4. 主語の焦点化}

本稿では, §2.1.3 で述べた機能を, “其” のもつ主要な機能のらちの一つと認めるか， Dobson 1962 のいう「強調」はもら少し詳 しく定義することができる。まず，次の例を 見られたい。

(3) a 子貢曰 ; “如有博施於民, 而能済衆, 何 如. 可謂化乎?” 子曰; “何事於仁. 必也 聖乎. 堯舜其猶病諸.”（論語・雄也）「子 し広く民に恩恵を施し，多数の民を救済す

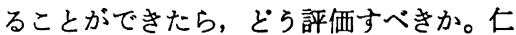
者と呼んでよろしいか？」「仁者どころで はない。きっと聖人たろら。堯舜ですら民 の救済には心を悩ましたではないか。」

b 趙嬰曰; “我在, 故轢氏不作。我亡, 吾 二昆其歪哉。”（左・成 5 ）「私がいるから, 査氏が謀反を起こさないのだ。私がいなく なったら，兄上二人もどんな迫害を受ける か。」

c 天其或者将建諸, 君其礼焉。（左 - 侸 23）「天はこれ（晋の公子）を助けて晋の 君にさせようとするのかもしれない。君は 公子を礼遇されるがよろしい。」

(3) a b の文で, “其” の前の主語は, 談話 に新しく導入された情報である。(3)cでは, 対照的に用いられている主語である。種々の 
文献中の例を見ても，“其”の前にある主語 は,この二つのどちらかにあてはまる場合が ほとんどである。この“其”は，新情報であ る主語や，対照的主語をよりいっそう際立た せ，聞き手の視点をそこに集中させるはたら きをしているのではないか。そらすると，(3) a b c の機能を果たす, この標識 “其” は, 「主語の焦点化 ${ }^{3)}$ を行っている，と定義し たほうがより正確であろら。

代名詞で主語を外置し，焦点化を抏こなう 言語は多い。特にピジン・クレオール言語に 多いが，例を一つ挙げておく。

HCE (ハワイにおけるクレオール英語)

A. sam gaiz samtaimz dei kam. (時々, 何人かがやってくる。) [下線部＝標識 $]$

some guys sometimes they come. [逐語 訳]

B. jaepan gaiz dei no giv a haeng, do. (で も日本から来た連中は打もしろがらないよ。)

Japan guys they no give a hang, though. [逐語訳]

(Bickerton 1981, 邦訳37より)

この言語では, 不定主語 (Aの例) と対照 的主語 (Bの例) の場合に標識が現れる。

上で述べた「主語の焦点化」を日本語の例 で解りやすく述べると，以下のようになる。 例えば，我々が，テレビで南極を特集した番 組を放送するとき，その番組の冒頭のナレー ションには,「南極は米の世界である。とい ら文よりも，「南極，それは氷の世界である。」 のような文を好むであろう。なぜならば，談 話に最初に登場する情報である「南極」を強 く印象つけけるには, 後者の文のように「南極」 が焦点化された文のほうがふさわしいからで ある(もっともこの種のレトリックは, 日本 語では今では陳腐なるのであるが)。

2.2. 代名詞以外のものととら古説

2.2.1. 品詞とその意味

過去の多くの研究・注釈書は, この “其” を次の(4)、に挙げるような品詞ととらえ，(4) bに挙げるような意味をもっているとする。 (4) a 副詞, 動詞, 助動詞, 語気助詞……

b 推測, 疑問, 反語, 将然, 未来, 命令, 意志.......

先に本稿の立場を明らかにしておく。筆者 の見た限り，主語と述語の間に “其” が現れ る文は，(4)bに挙げた意味をもつ場合がほと んどである。この点に関して, 先行諸説に異 論を差し挟む必要は認められない。しかし， (4) aに挙げられた品詞とする説は，“其”の 現れる位㯰からして認められない。このこと を次に述べる。

\subsection{2. “其” の位膡}

主語のある文では, “其” は主語の後に統 き(主語に先行することはない), 種々の助 動詞, 副詞に先行している。

（5）ａ＼cjkstart晋其庸可冀乎。（僖15）「晋はたやすく 手にはいれられまい。」

b 晋之公室甚将遂卑矣。（昭16）「晋の公 室は衰えようとしている。」

c 天其或者正訓楚也。（哀 1)「天がひ上 っとする楚を正し，いましめようとしてい るのかも知れない。」

d 楚師其猶在政邑之地下。（襄26）「楚の 軍隊はまだわれらの国にいるだろら。」

“其”のある位置は, 普通の文なら主語の ある位置である。副詞や助動詞・動詞等の占 める位置とは思われない。Dobson 1962 が, 「主語のあった位置を埋めている」とした観 察は正確である。また，語気助詞とする説は， 不自然である。語気助詞は，ふつう語・句・ 文末につく。この “其” は述語句に先行して いるのであって, 主語句に付加されているの ではない。それは，次の，

(6) a 其亦使逆君。（昭28）「今になってご主 君を迎えさせようとするのか。」

b 其造於竟。(昭28）「国境に行さなさ い.」

のように, 先の幾つかの文に比べ，主語がな いところたけが異なるとしか思えない文も多 
く存在するからである（本稿は, 主語のある むのから話を始めたが，この問題は(6)のよう に主語のない文も含めて論じなければならな いものである。このことは後で触れる)。

その他,「発語の辞」とする説むあるが, これも，位置の上から無理がある。ふつつう， “夫”など「発語の辞」に使われるものは, 文頭 (つまり主語があれば主語の前)にある。 発語の辞か，必ず主語と述語の間に現れねば ならぬ理由はない。

意味との関連からであるが，(4)b で挙げた ような多彩な意味をもつ「副詞, 助動詞, 動 詞」は考えにくい。語気助詞ならば,コンテ クスト次第で多様な意味をもつことが可能た が，出現する位置が異なることは既に述べ た。

その他，特筆すべき論考として，俞敏1949， 1987がある。これらでは, 先秦漢語の “其” を古代チベット語との関連で論じているが, 本稿で扱っているような“其”については, 古代チベット語の対応できらる形態素を挙げ て扣らず，「仮定の語気 “虚擬口気”」を表す， 句末に現れるのではない語気詞，としている (俞敏1987，82)。そして，「仮定の語気」が (4)bに示したような多様な意味を生むとして いる。「仮定の語気」を基本義とする分析に は異論はなく，賛成するが，文中に現れる語 気詞を認めるのは, 先にも述べたが, 先秦漢 語の文法体系全体（もちろんこれはまだ全貌 が明らかになっているわけではないが)から みて，どれほど妥当性のあるものたろらか。

\section{3. あるべき方向}

以上に二種類の説を紹介したが，その長短 をまとめてみる。まず，“其”が次の二つの 機能をるっていることを認める。

(7) a 主語の焦点化。

b「仮定の語気」を加える。

§ 2.1. で紹介した説は，(7)aをとらえよらと しているが，(7)bの説明はできない。ミ2.2. で紹介した説は，(7)bの現象を述べてはいる
が, 品詞としての地位の説明は不十分であり, また(7)aの説明はできない。

望ましい解決は，(7) a b の機能を同時に担 えるものとして，“其”を定義することであ る。そのために，次の章で代名詞 “其” の機 能として考えらるものを順にみていく。

\section{3. “其” の用法}

\section{1. 属格}

“其” は三人称代名詞の属格的な用法をむ つ(ここでいら「属格」とは名詞の決定詞と して使われるといらぐらいの意味である)。

(8) 観起 $\mathrm{i}$ 之死也, 其 $\mathrm{i}$ 子従在蔡……(昭13) 「観起が死んたとき，その子の従は蔡にい $\tau \cdots \cdots .$.

\section{2. 主語・目的語になる節}

また, “其” は, 文の主語, 動詞・前置詞 の目的語になる節の主語の位置に現れること もある。

(9) a 其使終㗽之, 亦不可知也。（哀15）「あ るいはそれ（天）が結局は（陳氏に）それ

(斉)を受け持たせるのかもしれない。」

b 而恐其使余往也……(昭30)「(王が)

私を将として遗わすのではないかと心配 ᄂ......」

c 以其不生得也……(昭29)「それ（竜）

は生け捕られないから…...」

この用法は上述の属格用法の拡張で, “其” を主語にもつ節は，すでに節全体が名詞的表 現になっている，としても構わないであろら

（またこの考えかたは特に目新しいものでは あるまい)。この名詞的表現になっている節 は, 英語の “It is hard to solve the problem.” の下線部のような構造（つまり不定 詞句) に，名詞的性質をもっているという点 で，機能的には近いものと思われる（英語の “to”之漢語の “其”が同じたというのでは ない)。そして本稿で主張したのは, このよ らな用法の発展として, 次の § 3.3. で述へ るような用法が現れたのではないかといらこ 
とである。

\section{3. 従属節}

3.3.1. 前提節

ある種の複文を次のようにわける。

(10)無理が通れば，道理がひっこむ。 [前提節] [㷌結節]

英語で，仮定法というムードをもつ複文が， 上の三つの節に分けて分析されることから， ヒントを得た。［前提節］とは，談話の中に 新しい場面を仮定し，話し手と聞き手の間に， 共通する発話の前提を築くものである。そし て，その結果どういらことになるであろら か，と仮定するのが [㷌結節］である。

“其”を主語にもつ節は, このような文の 前提節として使われることがある。以下の例 で，下線部二前提節。

(11) a 其亡也，以民為土芥。（哀 1）「それ （国）が滅びるときは，民を土や芥のよう に扱うものた。」

b 其有顮越不共, 即劓殁無遗育……(哀 11)「わがまま勝手で命令に従わないのがい れば, 断ち切って滅ぼし，子孫を残さず…」 c 其委諸伯父, 使伯父実重図之。(昭32) 「(私どもは)これらの仕事を拈じ上にまか せ，おし上上にかと重ねて取り計らっても らおら。」

d 若其無成, 君無屏焉。(昭26)「もし君 が成功しなくとも，君の恥にはならない。」 e 雖其善祝, 豈能勝億兆人之詛。(昭20) 「たとえそれら（神官たち）が心をこめて 祈ったところで，どらして億兆といら民の 呪いに勝つことがでさようか。」

(11) $\mathrm{a}-\mathrm{e}$ の前提節は, 条件, 仮定, 埕歩… などの意味で使われている。これらの節は, 基本的には仮定法的ムード（本稿はこの用語 を英語の「仮定法」を念頭において用いてい る）をむつがゆえにこのような前提節を形 成できる，としたい。それは，“其”を主語 にもつ節は, 名詞的表現であるがゆえに, 肯 定/否定の判断とは無縁であり, 時制とも無
縁であるから，未完了/未実現の出来事を叙 述すると解釈されるたろらからである。英語 と対照すれば, ここでの用法は, “To say frankly, you are wrong.” のような文の不 定司句 (下線部) を思い起こさせる。

(11) d e の “其”を“若, 雖” の接尾辞とみ なす説もあるが，そうしなければならない積 極的な理由もないようである。これらの語の 後に必ず “其”があるわけではないのだか ら。むしろ,これらの語が導く前提節では,

“其”をもつ節がよく使われることから，複 合しているよらに解釈されるようになったと いう仮説を提出することもできる。

\subsection{2. 帰結節}

帰結節に“其”を主語にもつ節が使われる こともある。以下の例では下線部＝帰結節。

(12) a 不款有事, 其告子也。(昭12）「わたし がおまえに用事ができたら，呼びにやろ 5。」

b 牛雖㾑, 傊於豚上, 其畏不死。（昭16） 「牛はやせていても豚の上に倒れれば, 豚 は恐れて死浪まっている。」

c 諸侯不知, 其謂我不敬。(昭20)「諸侯 はそれとは知らないで，我々が神を敬わな いのたというだろう。」

d 王心弗堪, 其能久乎。(昭21）「王の心 は（その鐘の音に）堪えられないたろらか ら，王は長生きできないだろら。」

e 是夫也, 其過三歳乎。(昭29）「この男

は，きっと三年も永らえないたろらっ」

上例の帰結節は, 意志, 推測, 反語……な どの意味をるつ。これはやはり，“其”を主 語にもつ節が仮定法的ムードをもつことが原 因で,コンテクストにより，上記の様々な解 勫を許す表現になったものと思われる。以下 に示寸英語の独立不定詞構文と, 構造の面か らも，機能の面からも類似の構文であろう。 (13) a To be young again!「む弓一度わか くなれたら!」

b To think that a boy should go ab- 
road for himself. 「考えてもごらんなさ い, 男の子が独りで外国に行くなんて。」

c I to marry him!「わたしが彼のお嫁 さんになるなんて!」

さて注意していただきたいのたが，(12) e は， 実は，「前提節」が「節」になっていない。 “是夫也”といら一句のみである(「この男に ついて言えば」ぐらいの意味であろら)。し かし, 帰結節に密着しているものではないこ とは, 助詞 “也” の存在が示している。そし て, 本稿が主㲀するのは以下のことである。 つまり，(12)の諸例のような帰結節をもち，

「前提節」が(12) e のように名詞句一個になり， それが(れよりも，もっと㷌結節に密着した とき，本稿で問題にしている，

(14) [王室 [其有間王位]]（昭26）

前提節由来帰結節

のような構造ができあがった。

\section{4. 結}

これまでに述べてきたことをまとめると次 のようになる。

・三人称代名詞 “其” の用法の展開

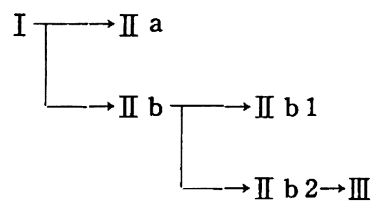

\section{I ．属格}

II. 名詞的表現になった節の主語
a . 主語, 目的語になる節の主語
b ．従属節の主語

1. 前提節の主語

2. 㷌結節の主語

III. 外置構文の標識

さて，この説明は，筆者自身が挙げたここ の問題の妥当な解決として認められるための 二つの条件 (§ 2.3.)
甲. 主語の焦点化 (の説明)。

乙. 仮定のムード (の説明)。

を満たしているか。

乙は問題ない。甲については，次のように 言える。つまり, 主語と述語の間に “其”が 挿入されることにより，主語は，[其__] となる帰結節の, 前提節としてあつかわれる。 前提節とは，新しい情況などを，聞き手と話 し手の共通の前提にするため，もちたすするの であるから，[前提節あつかい] $\Rightarrow[$ 焦点化 $]$ といえる。よって，“其” の挿入は，\$2.1.2 で挙げたハワイのピシン英語が, 代名詞の挿 入によって主語を外置し, 焦点化するのと, 同様の効果をもたらすことになる。[主語一 其一述語]といら形式の構文だけをとりだし て“其”の機能をいうなら，主語を外置する 役割を果たしているといってよい。

その他, “其”を代名詞由来のものと考え るなら，その前の主語が一・二人称の代名詞 である場合, “其”との人称の一致が問題に なるわけだがこれは，§ 2.1.2.で述べたよ らに，標識化する過程で一致をする機能を失 ったと解釈したい。思うに, 上述の II b ， III の “其”はすでに代名詞といらより, 文法的 な標識に近くなっているのではないたろらか。

また，“其”は上のII a の場合（誰にでも 代名詞と認められる場合) でも，話し手/聞 き手を指すことはよくある。

(15) 若羈 i (話し手) 也, 則君知甚 $\mathrm{i}$ 出也, 而未知甚 $\mathrm{i}$ 入也。(定 1)「わたしなどは， 君はわたしが（打供をして）出た心は知っ ているが，わたしが州るといらことは知ら ない。」

“其” の前に一・二人称の代名詞がくるの もそれほど不自然ではないのではないたろう か。

\section{〈注〉}

1) 本稿は, 中国語学会第38回全国大会 ('88. 10.30. 於神戸市外国語大学) で口頭発表し 
たものの一部に手を入れ文章化したもので ある。当日、コメントを寄せて下さった方 々に感謝を申し上け゚る。また，文章化にあ たって, 古屋昭弘先生, 畏友秋谷裕幸君に いろいろご指摘いたたいた。あわせて感謝 を申し上け゚る。無論, 本稿の不備な点はす べて筆者一人の責任に帰するものである。

2）現代日本語訳は，『新釈漢文体系 33 春 秋左氏伝』（鉡田正, 明治書院) に負 5 と ころが大きい。

3）焦点化とは, 発話の中にある要素を特に 際立たせる（聞き手に強く印象づける，聞 き手の視点をそこにひきつける）作業であ る。具体的には、ストレスを㯰く，有標な 位置に移動させる，といった操作であるこ とが多い。本稿で問題にする構造は，「有 標な位固への移動」を焦点化のための操作 として行っている。

以下, 英語の焦点化の例を幾つか举げ る。以下の例では，aに比べて b は下線部 が焦点化されている。

1 a . A car ran over Miké yesterday.

b. Miké was run over yesterday. 2 a. Miké was run over yesterday . b. It is yesterday that Miké was run over.

\section{〈文献目録〉}

Beveniste, E. 1966. Problémes de Linguistique Générale. Éditions Gallimard. Paris. [邦訳] 岸本通夫監訳1983.『一般言 語学の諸問題』。みすず書房。

Bickerton, D. 1981. Roots of Language. Karoma Publishers. Ann Arbor. [邦訳] 筧榖雄他訳 1985 .『言語のルーツ』大修館 書店。

Dobson, W. A.C. H. 1962. Early Archaic Chinese. University of Tronto Press. Tronto.

藤堂明保1953. 「上古漢語に打ける指示詞の 機能」。棟中国学会報 4 』, 1-17. [所 収]藤堂明保1987.『中国語学論集』。藤堂 明保中国語学論集編集委員会。汲古書院。 俞敏1949「汉语的 “其” 跟藏语的 $\mathrm{gji}$ 」。燕京 学报』, 37期。[所収] 俞敏1984.『中国語 学論文選』, 358-71. 光生館。

俞敏1987.『经传释词札记』。湖南教育出版社。 